\title{
Agrogenic changes in the redox potential in the profile of light-grey forest surface gleyed soils of the Western Forest-Steppe
}

\author{
Havryshko 0. ${ }^{1}$, Olifir Yu. ${ }^{2}$, Partyka T. ${ }^{3}$ \\ Institute of Agriculture of Carpathian region of NAAS \\ 5 Hrushevskoho Str., Obroshyne village, Pustomytiv region, Lviv oblast, 81115, Ukraine \\ e-mail: ${ }^{1}$ havryshko0@gmail.com, ${ }^{2}$ olifir.yura@gmail.com, ${ }^{3}$ tetyana.partyka@gmail.com
}

Goal. To study the change in redox potential (RP) in the profile of light-grey forest surface gleyed soil at different systems of fertilization and use. Methods. Field survey, physicochemical and comparative-analytical. Results. On the background of the calculated pHsalt and Clark index ( $\mathrm{rH} 2)$ the change was fixed in RP in the soil profile at long agrogenic impact. It was noted that durable plowing of the soil without fertilizers (control) for pHKCl 4,27 (average at 95\% probability) led to the predominance in the profile of moderate- and low-acid mode. At entering N105P101K101 + $10 \mathrm{t} / \mathrm{ha}$ of manure $+\mathrm{CaCO} 3(1.0 \mathrm{Ng})$ on the background of changes in the reaction of the soil solution of $\mathrm{pHKCl}$ it was fixed sharp transition with depth of RP from intense oxidative (628 MB) to weakly recovered (363 mV) mode, and rH2 index amounted to 31,2 - 20,2. Conclusions. Use on acidic light-grey forest surface gleyed soil of organic-mineral fertilizer system in the dose of N105P101K101 + $10 \mathrm{t} / \mathrm{ha}$ of manure $+\mathrm{CaCO} 3(1.0 \mathrm{Ng})$ created the best conditions for the formation of intensive oxidation processes. Prolonged plowing of the soil without fertilization (control) caused the development in the profile of weakly oxidized processes. Systematic entering in the soil of some mineral fertilizers (N65P68K68) compared with the control and organic-mineral system of fertilizing contributes to a noticeable reduction of redox potential in the direction of the recovery processes. In order to study optimal doses of fertilizers and lime and to ensure balanced natural cycles of substances of acidic light-grey forest surface gleyed soils under different levels of agricultural loads, it is advisable to use RP as a highly sensitive performance indicator, which allows to quantitatively establish the deviation of the redox state of soil natural balance.

Key words: redox processes, index, horizon, fertilizers, acidity.

DOI: https://doi.org/10.31073/agrovisnyk202002-03

Soil redox potential (ORP) is one of the most important properties that controls various chemical and biochemical processes. Redox conditions are not uniform in the soil matrix and homogeneous in individual genetic horizons, as they are constantly affected by microbial processes, oxygen concentration, organic matter content, groundwater status, $\mathrm{pH}$, etc. [1-3].

Under the conditions of pronounced surface hydromorphism, its high seasonal and profile contrast, a sharp change in the ORP occurs. It leads to the formation of nodules, to intensification of iron removal processes of the mineral ferro-aluminosilicate part of the soil, entry and solidification of individual plant nutrients $(\mathrm{P}, \mathrm{Fe}, \mathrm{Ca}, \mathrm{Mn}, \mathrm{Si}$, etc.) in crystallized segregation and their removal from the nutrient soil fund [4]. However, the absolute values of redox potential do not always adequately reflect the oxidation/reduction conditions created in different agroecosystems, as the intensity of oxidative and reductive processes is significantly affected by soil acidity [5].

Oxidation/reduction reactions and acid-base reactions are necessary to support all living organisms. However, redox potential in soil (Eh) has received little attention in agronomy, unlike $\mathrm{pH}$, which is regarded as a major indicator. Agronomists are probably depriving themselves of a key factor in crop and soil, which can be a useful integrative tool [6-7].

Therefore, to obtain comparative data of the redox conditions generated by different fertilizer systems, and therefore different acidity, in particular $\mathrm{pH}_{\mathrm{Kcl}}$, we use Clark's index $\left(\mathrm{rH}_{2}\right)$ [8-9].

$$
\mathrm{rH}_{2}=\frac{E h}{30}+2 \mathrm{pH}
$$

The purpose of the research is to determine the change of redox potential in the profile of light gray forest surface-gleyed soil under agrogenic exposure.

Research methodology. The study was conducted during the 2015-2017 in long-term stationary experiment, established in 1956 in the Institute of Agriculture Carpathian region NAAS on light gray forest surface-gleyed soil with different doses and ratios of fertilizers, manure and lime.

The stationary experiment is located on three fields; each has 18 variants, which have a threefold repetition. The location of the variants is single-tier, consequent. The total area of the plot is $168 \mathrm{~m}^{2}$, the accounting area is $100 \mathrm{~m}^{2}$. 
Investigation ORP changes by soil profile was carried out during the IX rotation of crop rotation during winter wheat growing in the variants: absolute control (without fertilizer application) (var. 1), organo-mineral fertilizer system (10 $t /$ ha of rotation area of manure $\left.+N_{105} P_{101} K_{101}\right)$ against the background of periodic liming with $1.0 \mathrm{n} \mathrm{CaCO}_{3}$ according to $\mathrm{Ha}\left(7.0 \mathrm{t} / \mathrm{ha}\right.$ of limestone flour) (var. 7) and mineral fertilizer system alone $\left(\mathrm{N}_{65}\right.$ $\mathrm{P}_{68} \mathrm{~K}_{68}$ ) (var. 15).

Agrochemical characteristics of the soil arable layer before starting experiment were: the content of humus according to Tyurin $-1,42 \% ; \mathrm{pH}_{\mathrm{kCl}}-4.2$; hydrolytic acidity (according to Kappen) - 4,5; exchangable acidity (according to Sokolov) - 0,6 mmol/100 $\mathrm{g}$ of soil; content of movable Aluminium (according to Sokolov) - 60,0 mg/kg; available phosphorus (according to Kirsanov) and exchangeable potassium (according to Maslov) -36.0 and $50.0 \mathrm{mg} / \mathrm{kg}$ of soil respectively.

Semi-precipitated cattle manure on straw bedding, ammonium nitrate (34.5\%), granulated superphosphate $(19.5 \%)$, potassium salt $(40 \%)$, nitroamophos (NPK $16 \%$ ) were used in the experiment (using NPK, content was balanced according to fertilizer levels by simple fertilizers). Manure (40-60 t/ha) was introduced under the corn. Phosphorus-potassium fertilizers were introduced in the fall, nitrogen - under pre-sowing cultivation. Liming, according to the scheme of the experiment, was carried out before the start of IX rotation, in which the dose of fertilizer for crop rotation was also adjusted. Limestone flour $\left(93.5 \% \mathrm{CaCO}_{3}\right)$ was used as the limestone fertilizer. Cultivation technology is generally accepted for the conditions of the Western Forest-Steppe zone of Ukraine.

Redox potential was measured during the winter wheat growing season in the field using a platinum and chlorine silver electrode according to DSTU ISO 11271: 2004 [10-11]. The measurement of the $\mathrm{pH}_{\mathrm{kCI}}$ was conducted by the potentiometric method according to DSTU ISO 10390-2001. The results of laboratory studies were statistically processed according to conventional methods Ye. A. Dmitriev and B. A. Dospekhov using the method of variational statistics [12-13].

Results. It was found that prolonged ploughing (more than 50 year) of light gray forest surface-gleyed soil on variant without fertilization (control), the ORP's profile varied from mild oxidative $514 \mathrm{mV}$ in arable and subsoil horizon to weak oxidative $494 \mathrm{mV}$ in eluvial slightly humic (Ehgl) and $458 \mathrm{mV}$ in illuvial slightly eluvial (legl) gleyic horizons (Table. 1).

\section{Scale of redox potentials (according to N. K. Khtryan) [14]}

\begin{tabular}{|c|c|}
\hline The nature of the processes & ORP, $\mathrm{mV}$ \\
\hline Intensively reductive & $<200$ \\
\hline Moderately reductive & $200-300$ \\
\hline Weakly reductive & $300-400$ \\
\hline Weakly oxidizing & $400-500$ \\
\hline Moderately oxidizing & $500-600$ \\
\hline Intensively oxidizing & $>600$ \\
\hline
\end{tabular}

Note. The above scale is used to characterize the redox conditions of soils, however, the degree of detail and the boundaries of the intervals require further improvement and refinement.

From this it follows that long rotation, plowing of organic residues (stubble, II clover meadow) on the control without fertilizer application leads to the development of genetic horizons. OB processes (Table 2).

The $\mathrm{pH}_{\mathrm{KCl}}$ indicator in the control experienced subsequent changes, where it amounted to 4.22, 4.18; 4.31 ; 4.13 units respectively (confidence interval (average) $X \pm S X-4.27$ with an error of 0.04 ). Lowoxidation conditions $(446 \mathrm{mV})$ at $\mathrm{pH}_{\mathrm{KCl}} 4.22-4.47$ were observed in the illuvial $(446 \mathrm{mV})$ and transitional to rock $(440 \mathrm{mV}$ ) horizons. In strongly illuvial gleyic parent rock (Plgl) ORP was at the level of $437 \mathrm{mV}$. From this it follows that long-term crop rotation, ploughing of organic residues (stubble, 2nd mow of meadow clover) on the control without use of fertilizers leads to the development of weakly oxidizing redox processes in the soil genetic horizons (table. 2).

2. Change of redox potential in the profile of light gray forest surface-gleyed soil depending on various anthropogenic pressures, 2015- 2017 years

\begin{tabular}{|c|c|c|c|c|}
\hline $\begin{array}{c}\text { Genetic } \\
\text { horizons }\end{array}$ & $\begin{array}{c}\text { Horizon } \\
\text { thickness, cm }\end{array}$ & $\mathrm{pH}_{\mathrm{KCl}}$ & Eh, $\mathrm{mV}$ & $\mathrm{rH}_{2}$ \\
\hline 1 & 2 & 3 & 4 & 5 \\
\hline \multicolumn{5}{|c|}{ Without fertilizers (control) (var 1) } \\
\hline HEglarable & $0-18$ & 4.22 & 514 & 25.6 \\
\hline $\mathrm{HEglsubsoil}$ & $18-31$ & 4.18 & 514 & 25.5 \\
\hline Ehgl & $31-64$ & 4.31 & 494 & 25.1 \\
\hline legl & $64-110$ & 4.13 & 458 & 23.5 \\
\hline Igl & $110-131$ & 4.22 & 446 & 23.3 \\
\hline IPgl & $131-180$ & 4.47 & 440 & 23.3 \\
\hline Plgl & $180-200$ & 4.35 & 437 & \\
\hline
\end{tabular}




\begin{tabular}{|c|c|c|c|c|}
\hline- & $\bar{X} \pm S_{\bar{x}}$ & 4.27 & - & - \\
\hline- & $S_{\bar{x}}$ & 0.04 & - & - \\
\hline- & $V, \%$ & 2.7 & - & - \\
\hline- & $S$ & 0.12 & - & - \\
\hline- & $H I P_{05}$ & 0.15 & - & - \\
\hline \multicolumn{5}{|c|}{$\mathrm{N}_{105} \mathrm{P}_{101} \mathrm{~K}_{101}+10 \mathrm{t} / \mathrm{ha}$ manure $+\mathrm{CaCO}_{3}(1.0 \mathrm{Ha})($ Var. 12) } \\
\hline HEglarable & $0-20$ & 5.15 & 628 & 31.2 \\
\hline $\mathrm{HEgl}_{\text {subsoil }}$ & $20-33$ & 5.10 & 575 & 29.3 \\
\hline Ehql & $33-51$ & 4.24 & 560 & 27.1 \\
\hline legl & $51-77$ & 3.88 & 420 & 21.7 \\
\hline Igl & $77-138$ & 3.85 & 388 & 20.6 \\
\hline IPgl & $138-187$ & 3.97 & 370 & 20.2 \\
\hline PIGI & $187-210$ & 4.05 & 363 & 20.2 \\
\hline- & $\bar{X} \pm S_{\bar{x}}$ & 4.32 & - & - \\
\hline - & $S_{\bar{x}}$ & 0.21 & - & - \\
\hline- & $V, \%$ & 13,1 & - & - \\
\hline- & $S$ & 0.56 & - & - \\
\hline- & $\mathrm{HIP}_{05}$ & 0.74 & - & - \\
\hline \multicolumn{5}{|c|}{$\mathrm{N}_{65} \mathrm{P}_{68} \mathrm{~K}_{68}$ (Var. 15) } \\
\hline 1 & 2 & 3 & 4 & 5 \\
\hline HEglarable & $0-22$ & 4.03 & 426 & 22.3 \\
\hline HEgl subsoil & $22-35$ & 3.98 & 416 & 21.8 \\
\hline Ehgl & $35-61$ & 4.17 & 398 & 21.6 \\
\hline legl & $61-87$ & 4.00 & 368 & 20.3 \\
\hline Igl & $87-150$ & 4.07 & 323 & 18.9 \\
\hline$\overline{\mathrm{IPgl}}$ & $150-180$ & 4.04 & 318 & 18.7 \\
\hline PIGI & $180-200$ & 4.11 & 311 & 18.6 \\
\hline- & $\bar{X} \pm S_{\bar{x}}$ & 4.06 & - & - \\
\hline- & $S_{\bar{x}}$ & 0.02 & - & - \\
\hline- & $V, \%$ & 1.6 & - & - \\
\hline- & $S$ & 0.07 & - & - \\
\hline- & $H_{I I P_{05}}$ & 0.09 & - & - \\
\hline
\end{tabular}

Note. $\bar{X}^{ \pm} S_{\bar{x}}$ - confidence interval (mean) for $95 \%$ probability; $S_{\bar{x}}$ - standart error; $\boldsymbol{V}, \%$ coefficient of variation (index of variability of a numerical series); $\boldsymbol{S}-$ standard deviation.

More contrasting change in the ORP was observed in the profile of light gray forested surface-gleyed soil compared to the control (var. 1) in the organo-mineral fertilizer system with the background of liming with a full dose of $\mathrm{CaCO}_{3}$ according to $\mathrm{Ha}$ (var. 12). Increased value of redox potential to $628 \mathrm{mV}$ in the HEglarable horizon indicates the development of intensively oxidizing processes (table. 1). In HEglsubsoil and Ehgl horizons, oxidation/reduction processes according to Clark indicators 29.3 and 27.1 were characterized as moderately oxidizing. In the legl horizon $(51 \mathrm{~cm}$ depth) Eh potential difference dramatically changed from weakly oxidizing $(420 \mathrm{mV})$ to weakly reductive processes in lower-lying Igl and IPgl genetics horizons, 388 $370 \mathrm{mV}$ respectively. The lowest boundary of the weakly reductive redox-mode $(363 \mathrm{mV})$ and Clark's index (20.2) under such fertilizer system was observed in the highly illuvial and the highly gleyic parent rock (PIGI) at $4.05 \mathrm{pH}$ kcl.

Attention should be paid to the increased $(13.1 \%)$ coefficient of variation $(V)$ of the soil $\mathrm{pH}$ in 12th variant. It indicates a wide range of changes in the reaction of the soil solution (from 5.15 to 4.05 ) and its relation to the redox potential in profile (table. 2).

Studies have shown that long-term use in the experiment mineral fertilizers alone in a dose of $\mathrm{N}_{65} \mathrm{P}_{68} \mathrm{~K}_{68}$ (var. 15) contributed to a decrease in ORP in the direction of reduction processes in the profile compared to the control without fertilizers and the organo-mineral fertilizer system. Highest ORP values were obtained in the humus-eluvial arable $(0-22 \mathrm{~cm})$ and sub-arable $(23-35 \mathrm{~cm})$ layers: 426 and $416 \mathrm{mV}$ respectively. In underlying horizons ORP decreased from $398 \mathrm{mV}$ to $318 \mathrm{mV}$ at $\mathrm{pH}_{\mathrm{Kcl}} 4.17-4.04$, which characterizes the processes occurring in them as weakly reducing and close to moderately reducing, and remained so up to PIGI (311 mV) (Table 2). Subsequently, under such conditions, on acidic light gray forest surface-gleyed soils, a decrease in the redox potential will cause an excessive accumulation of plant toxic compounds $\mathrm{Fe}^{2+}$, $\mathrm{Mn}^{2+}, \mathrm{Al}^{3+}[15]$, which will lead to even more acidification of the soil and adversely affect the nutrition of the plants, which will ultimately reduce the crop yield in crop rotation. 


\section{Conclusions}

Thus, the use of an acidic light gray forest surface-glowing soil of the organo-mineral fertilizer system at a dose of $\mathrm{N}_{105} \mathrm{P}_{101} \mathrm{~K}_{101}+10 \mathrm{t} / \mathrm{ha}$ of manure $+\mathrm{CaCO}_{3}(1.0 \mathrm{Ha})$ creates the best conditions for the formation of intensively oxidative processes. Prolonged plowing of soil without fertilizer application (control) leads to the development in the profile of weakly oxidized processes. The systematic application of mineral fertilizers $\left(N_{65} P_{68} K_{68}\right)$ into the soil as compared to the control and organo-mineral fertilizer system contributes to a significant reduction of the redox potential in the direction of recovery processes. For substantiation of optimum doses of fertilizers and lime and ensuring balanced natural cycles of the circulation of substances of acidic light gray forest surface-charred soils at different levels of agricultural load, it is advisable to use as a highly sensitive estimation indicator a redox potential soil from its natural equilibrium.

\section{References}

1. Natsionalna dopovid pro stan navkolyshnoho pryrodnoho seredovyshcha v Ukraini u 1999 rotsi Ministerstva ekolohii ta pryrodnykh resursiv Ukrainy. (2000) [National Report on the State of the Environment in Ukraine in 1999 by the Ministry of Ecology and Natural Resources of Ukraine]. Kyiv: Rajewski Publishing House. [In Ukrainian]

2. Husson, O. (2013). Redox potential (Eh) and $\mathrm{pH}$ as drivers of soil/plant/microorganism systems: A transdisciplinary overview pointing to integrative opportunities for agronomy. Plant Soil, 362, 389-417.

3. Simek, M., \& Cooper, J. E. (2002). The influence of soil pH on denitrification: progress towards the understanding of this interaction over the last 50 years. Eur. J. Soil. Sci., 53, 345-354.

4. Truskavetskyi, R. S., Zubkovska, V. V., \& Khyzhniak, I. M. (2015). Rol hidromorfizmu v rodiuchosti gruntiv [The role of hydromorphism in soil fertility] Foothill and mountain agriculture and stockbreeding, 58 (1), 199-211. [In Ukrainian]

5. Mamontov, V. G. (2006). Obshchee pochvovedenie [General Soil Science]. Moskva: Kolos. [In Russian]

6. Hopkins, W. G., \& Huner, N. P. (2009). Introduction to Plant Physiology (4th ed.). New York: John Wiley \& Sons, Inc.

7. Seo, D. C., \& DeLaune, R. D. (2010). Effect of redox conditions on bacterial and fungal biomass and carbon dioxide production in Louisiana coastal swamp forest sediment. Science Total. Environment, 408, 3623-3631.

8. Greenberg, R. C. (1998). Understanding the redox $(\mathrm{rH} 2)$ measurement of the biological terrain: Part I. Biomed Therap., 16, 156-158.

9. Fiedler, S., Vepraskas, M. J., \& Richardson, J. L. (2007). Soil redox potential: Importance, field measurements, and observations. Adv Agron, 94, 1-54.

10. DSTU ISO 11271: 2004. Yakist gruntu. Vyznachennia okysno-vidnovnoho potentsialu. Polovyi metod. Chynnyi vid 01. 05. 2006. [National Standards of Ukraine ISO 11271: 2004. Soil quality. Determination of redox potential. Field method. Effective from 05/05/2006]. Kyiv: State Consumer Standard of Ukraine. [In Ukrainian]

11. Cheshko, N. F., \& Tsapko, Yu. L. Patent no. 50067 Ukraine, MPK G01N 33/24. Sposib potentsiometrychnoho vymiriuvannia okysno-vidnovnoho potentsialu $v$ grunti [Method for potentiometric measurement of redox potential in soil]; no. u2009 11887; stated 25.05.2010. 6 p. [In Ukrainian]

12. Dmitriev, Ye. A. (1972). Matematicheskaya statistika v pochvovedenii [Mathematical statistics in soil science]. Moscow: Izd-vo MGU. [In Russian]

13. Dospekhov, B. A. (1985). Metodika polevogo opyta (s osnovami statisticheskoy obrabotki rezultatov issledovaniy) [The methodology of field experience (with the basics of statistical processing of research results)]. (5th ed.). Moscow. [In Russian]

14. Khtryan, N. K. (1976). Osnovnye zadachi i obshchie metody izucheniya pochvennogo rezhima. [Main tasks and general methods of studying the soil regime]. Proceedings of the Research Institute of Soil Science and Agrochemistry of the Ministry of Agriculture. Armenian SSR, 1, 28-34. [In Russian]

15. Kyrylchuk, A. A., \& Bonishko, O. S. (2011). Khimiia gruntiv. Osnovy teorii i praktykum: navch. posib. [Soil chemistry. Fundamentals of Theory and Workshop: Tutorial]. Lviv: Ivan Franko National University. [In Ukrainian] 